\title{
限外沪過法による血等中遊離型バルプロ酸の定围*1
}

\author{
藤田育志, 早勢伸正, 稲垣俊一, 橋高 媇 \\ 旭川医科大学医学部附属病院莱郕部*2

\section{Determination of Serum Free Valproic Acid by Ultrafiltration Method*1}

\author{
YASUYUki Fujita, Nobumasa Hayase, Shunichi \\ INAGAKI, and TAKESHI KITUTAKA \\ Department of Hospital Pharmacy, Asahikawa Medical College Hospital*ః
}

(Received February 21, 1983)

\begin{abstract}
The assay of free form of valproic acid (VPA) in serum was made on 71 serum specimens of epileptic patients. For the isolation of free VPA, ultrafiltration using micropartition system MPS-1(Amicon Corp.) was applied and it was confirmed that this system was good in utility. For the lower levels of VPA as in ultrafiltrates, a modified single dilution technique was developed in EMIT assay instead of the standard clouble dilution procedure. The results were compared with those determined by the gas-liquid chromatography. Results determined by the above two methods were correlated well $(r=0.982)$ and the regression line was $y=1.023 x-$ 0.143. Ultrafiltration using MPS -1 is very simple and practical, because it requires small amount of serum sample. In 20 serum specimens from patients treated with VPA alone, the mean percentage of free VPA was $12.5 \pm 3.9 \%$. The percentage of free VPA and total VPA levels showed a positive correlation $(r=0.808)$.
\end{abstract}

Keywords_-valproic acid; ultrafiltration; serum free valproic acid; homogeneous enzyme immunoassay; gas-liquid chromatography

\section{はじめに}

抗てんかん薬であるバルプロ酸 (以下 VPA と略す.) 泣，多くの莱物と同槏に体内に吸収され一部が血鼎蛋白 と結合し，残りは蛋白非結合型（遊離型）で存在してい る. 遊離型が薬効発現に夙係深くこれを測定すること 汇臨床的意義が大きいと考えられる．しかしこの遊離型 を測定するためには血中から蛋白結合型と遊離型を分離 ナる必要がある。

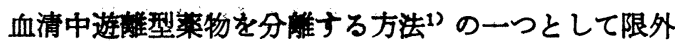
沪過法があるが，従来この方法は比較的多量の血清を必 磊とするため, 少量の患者血清を扱う臨床の場で実際に 用いることは容易でなかった．著者らは限外汇過法の一

*1 本啹の一部は第29回北海道桼学大会(札幅，1982年 6月）で報告した。

*3. 娱川市西神楽 4 線 5 号 3 番地 11；3-11，4Sen 5Go, Nishikagura, Asahikawa-shi, 078-11 Japan
つであり少量の血清を処理できる遠心型蛋白結合試験器 MPS-1 (アミコン社製)を用いて，患者血清から遊離型 VPAを分離し湍度を求めた。

本報告で，MPS-1 飞补ける限外汇過膜 (メンブラ ンフィルター）の蛋白分離性能，および VPA に対する 影管ならびKメンブランフィルターの均一性について検 討した.さらに血清中遊離型 VPA の定量は，醅素兔废 渭定法 (以下 EMIT 法と略す.) を利用した低流度眣定 法によって行った。この方法とガスクロマトクラフ法 （以下 GLC 法と略す.)とを比慗しその相网性を調へた。. また血清中 VPA 総注度を EMIT 法および GLC 法で 测定し遊磪型\%を算出したので報告する。

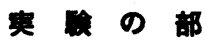

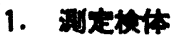

坥川医科大学病院小児科火おいて，VPA を単独ある いは他の抗てんかん薬と併用服用中のてんかん患者から 
Table 1. Samples from Patients Treated with Antiepileptic Drugs

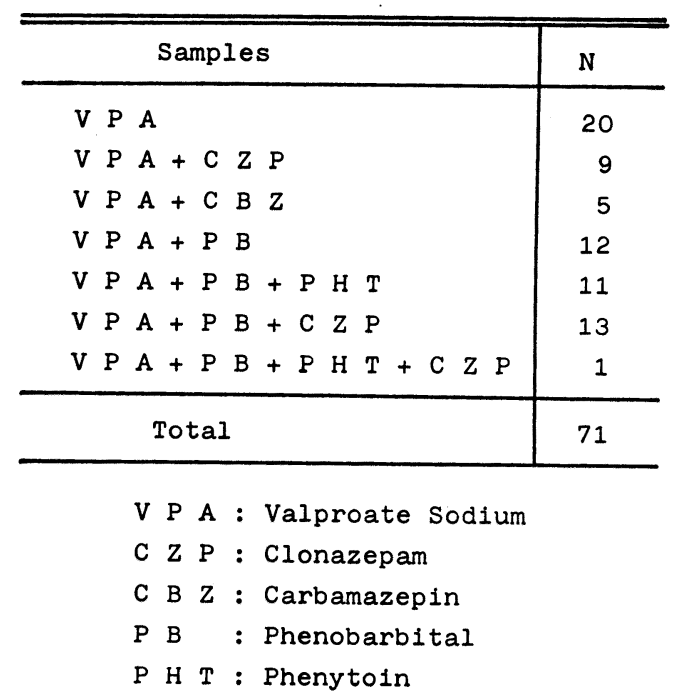

採取した血清71検体を対象とした（Table 1). 検体は測 定時まで冷凍庫中に保存した。

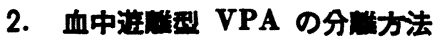

Fig. 1 に示す遠心型蛋白結合試験器 MPS-1 に血清を 入れ, KUBOTA KN-70 型遠心分離器で毎分 3400 回転 で30分間遠心分離を行い, 遊離型 VPAを分離した。

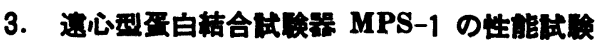

1）メンブランによる血漿蛋白阻止率の検討試験 健常人血清の総蛋白量をビューレット法る)で測定し， この血清を限外沪過した汇液についてはモェレマンス

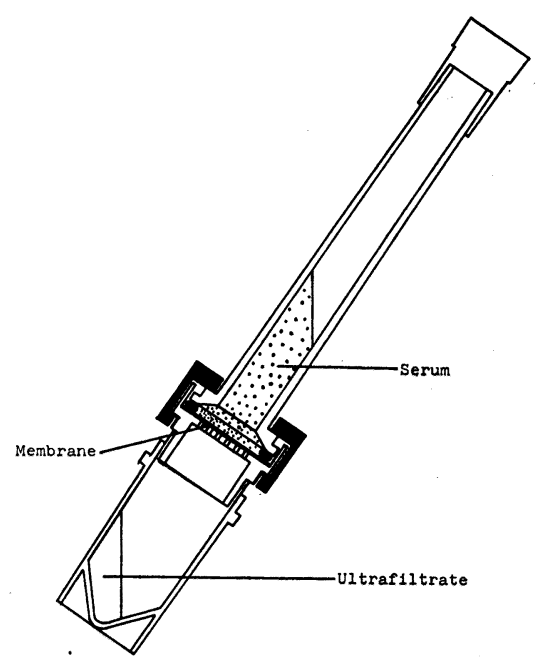

Fig. 1. Principle of Ultrafiltration

法2)で測定し阻止率を求めた.

2) メンブランの VPA に対する影響試験

VPA（協和酲酵工業株式会社）を生理食塩液で 5 段階 の濃度 $(20,40,60,80,100 \mu \mathrm{g} / \mathrm{ml})$ 飞調製した試験液を限 外汇過し，その汇液と沪過残液に打ける VPA 濃度を EMIT 法で測定して比較した.

3) メンブランの均一性試験

同一ロットのメンブラン10枚を用いて患者のプール血 清を限外汇過し, その沪液における VPA 濃度を EMIT 法で測定した。

\section{EMIT 法による VPA の測定}

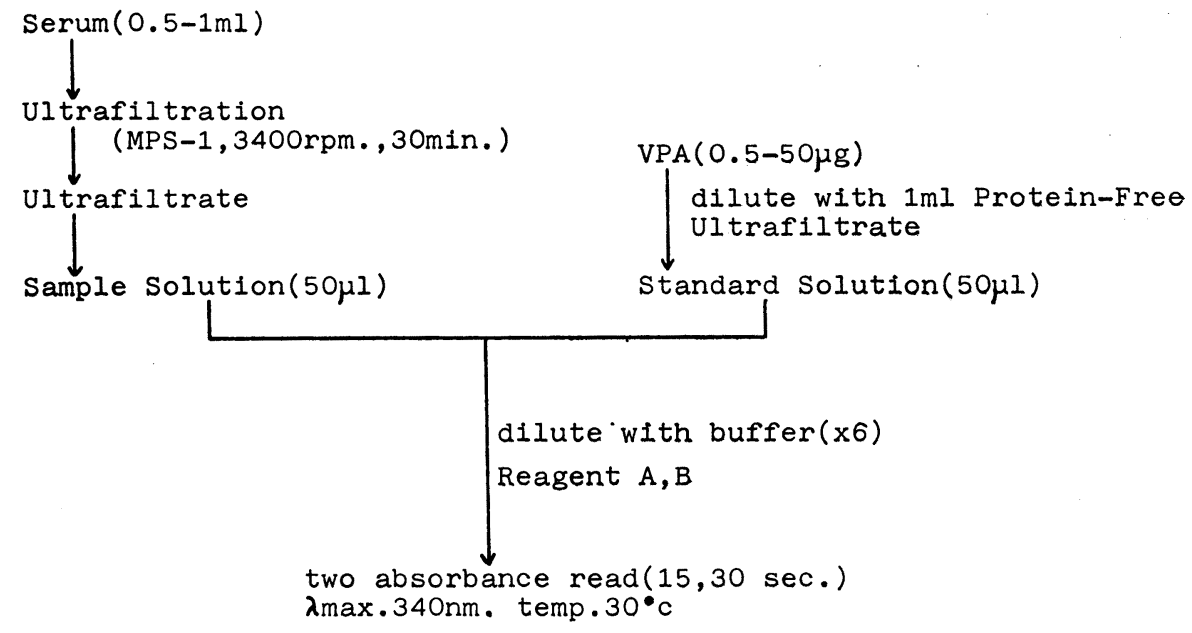

Fig. 2. EMIT for Free VPA Levels 


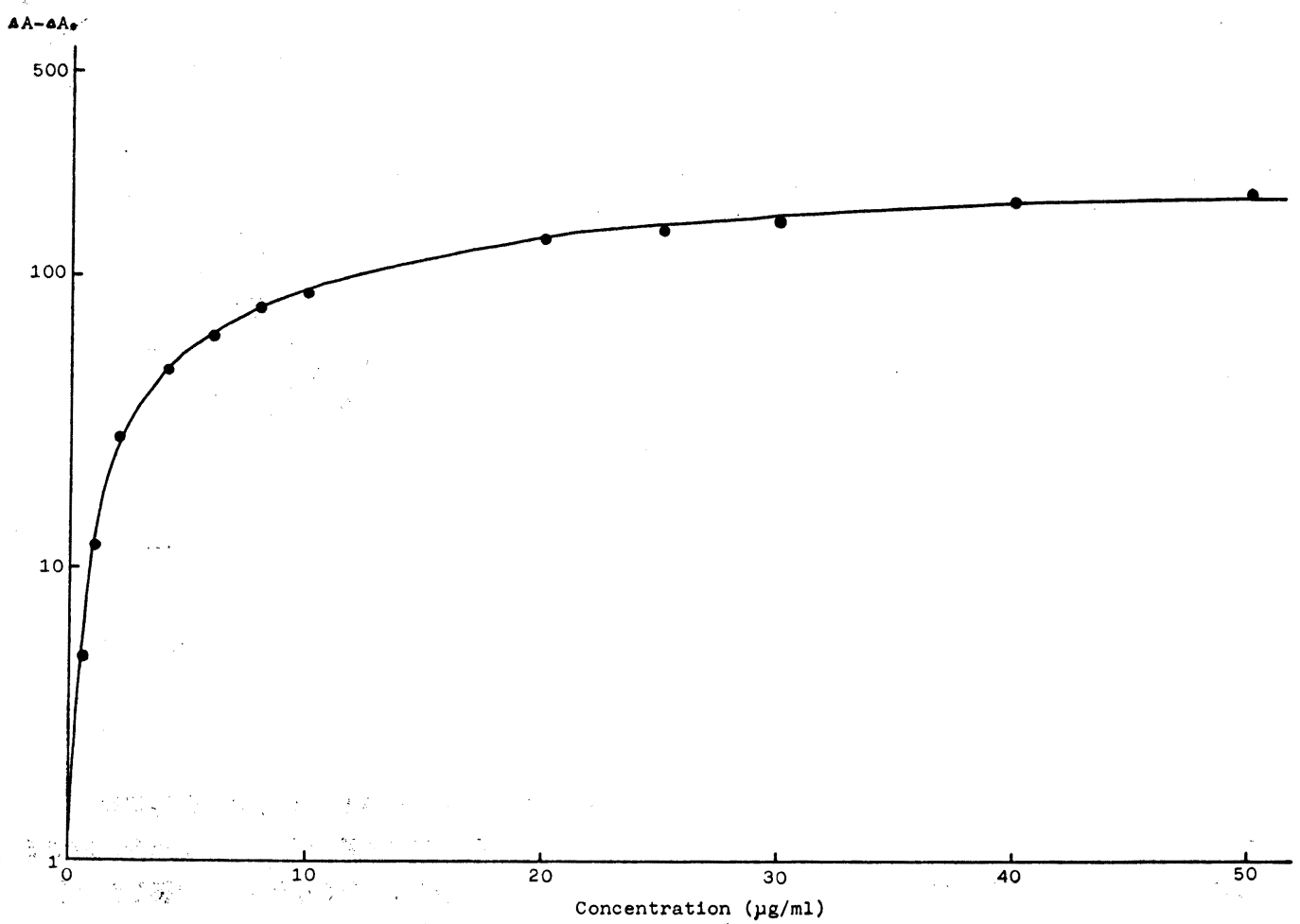

Fig. 3. Standard Curve for Free VPA Levels (EMIT)

1) 血清中 VPA 総濃度の測定

EMIT VPA Assay Kit (Syva 社製) を用い, 常法 にしたがって操作し，EMIT 専用グラフ用紙による検量 線から求めた。

2）血清中遊離型 VPA 濃度の測定

血清検体 0.5-1 ml を MPS-1 飞入れ遠心分離器で限 外汇過し，その沪液を試験溶液とした．また，健常人血 清を同様に処理して得た汇液にVPAを加えて 0.5-50 $\mu \mathrm{g} /$ $\mathrm{ml}$ の浱度に調製し，これを標準溶液とした．Fig. 2 に 示すように試験溶液および標準溶液を各々 $50 \mu 1$ とり, 緩衝液で 6 倍に 1 次希翻の及行い，後は常法にしたがっ

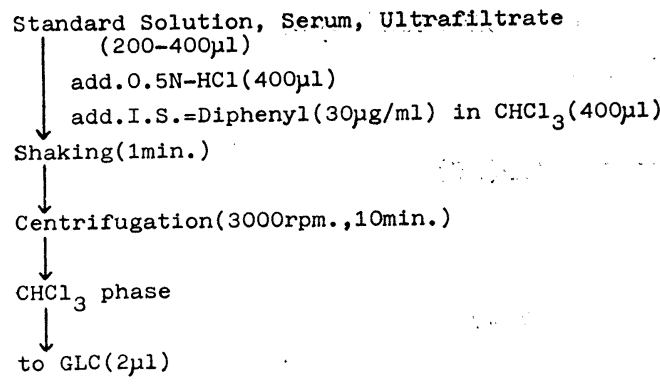

Fig. 4. GLC Method for VPA
て測定した。標準溶液から得た検量線を Fig. 3 亿示し た. 縦軸に吸光度差を対数目盛でとり, 横軸には浱度を とって二次曲線が得られた。

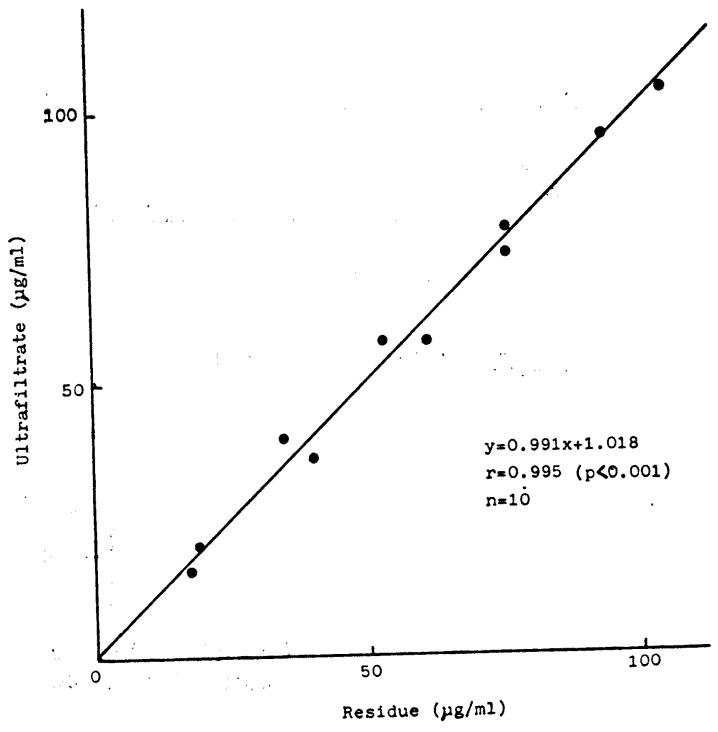

Fig. 5. Influence of Membrane to VPA 


\section{GLC 法による VPA の湴它}

血清中 VPA 総浱度,ならびに遊崔型灌度はいずれる

Fig.4に示すよらに掛川, 3) 幸田(`らの方法に準じて測定
した。すなわち、試料あるいは標準液を塩酸酸性とし内 部標準物質としてジフェニルを加え、クロロホルムで振 とう抽出し，遠心分離後ク口ロホルム層 $2 \mu 1$ を日立 163

Table 2. Uniformity of Membrane

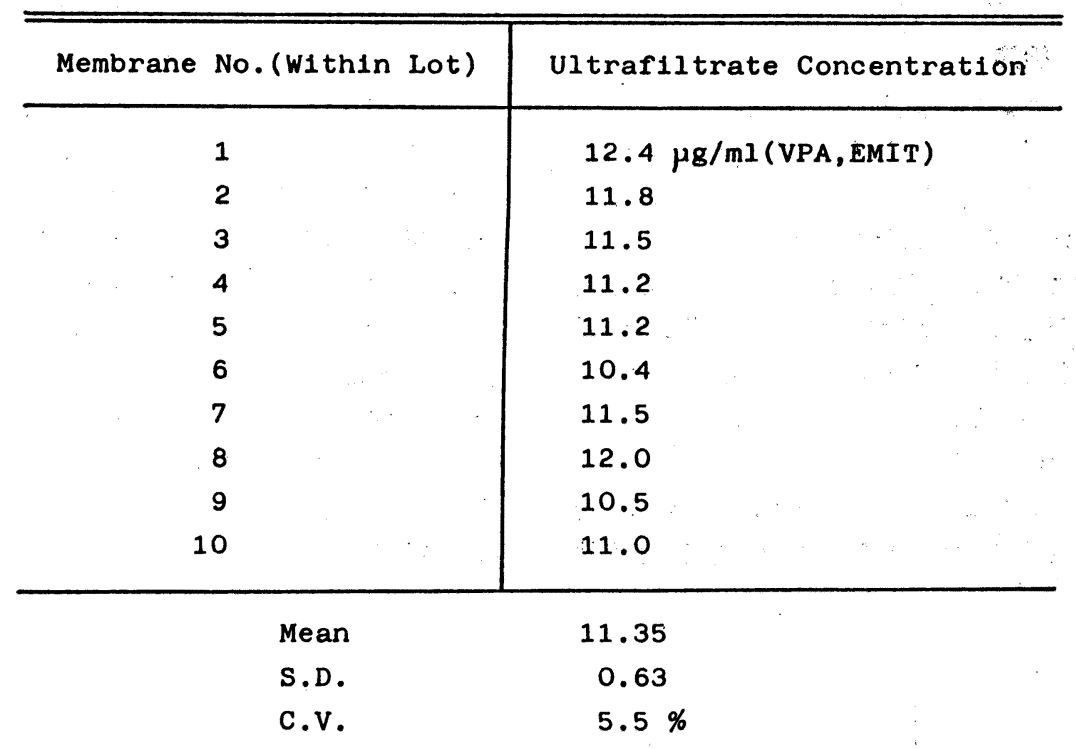

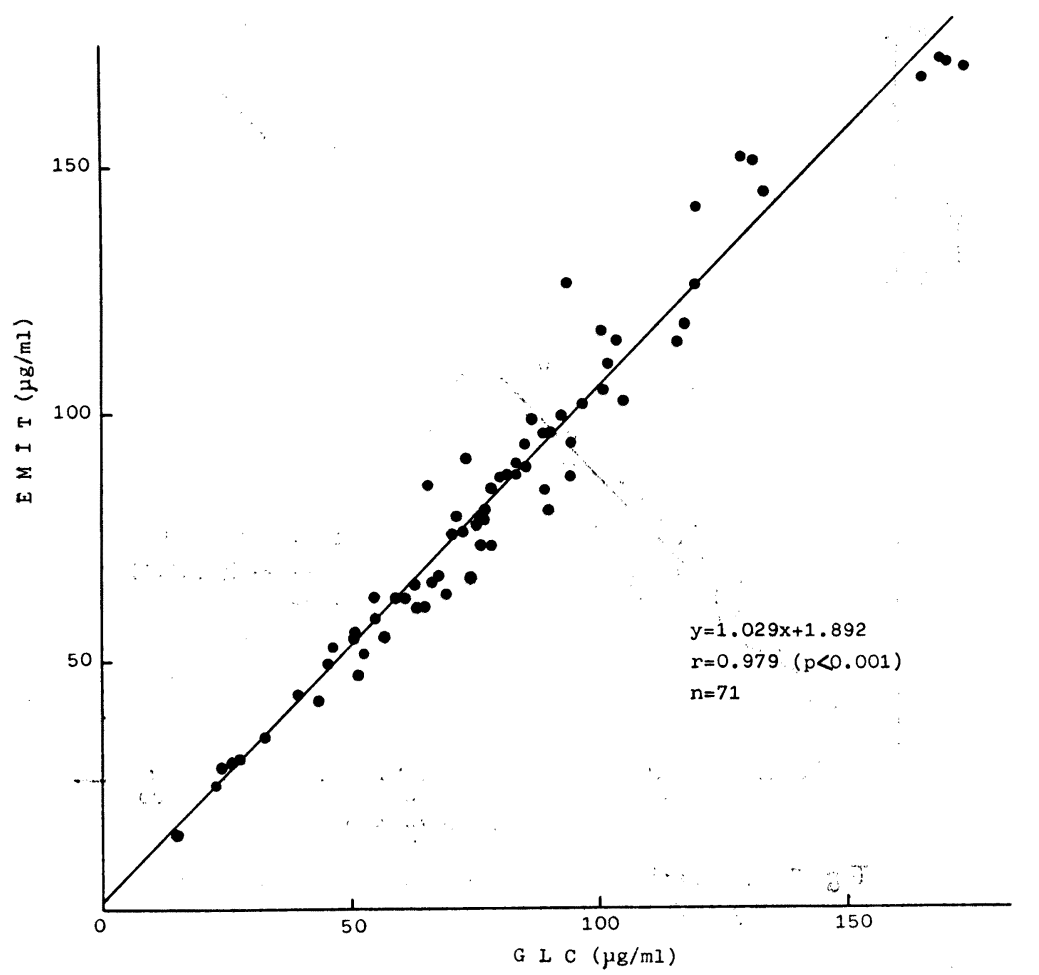

Fig. 6. Comparison of Total VPA Levels Determined by EMIT and GLC 
型ガスクロマトグラフに注入し検量線から求めた. GLC の条件は，充てん剤として $5 \%$ DEGS- $\mathrm{H}_{3} \mathrm{PO}_{4}$ を用い， カラム温度 $130^{\circ}$,キャリアーガス $\mathrm{N}_{2} 35 \mathrm{ml} / \mathrm{min}, \mathrm{FID} て ゙$ 分析した.

\section{轺果および考橰}

\section{MPS-1 の性能}

1）メンブランによる血漿蛋白阻止率

健常人血清の総蛋白量は $6.5 \mathrm{~g} / \mathrm{dl}$, 限外汇過した汇液 のそれは $3 \mathrm{mg} / \mathrm{dl}$ で，阻止率は $99.95 \%$ であった。

2）メンブランの VPA に対する影響

Fig. 5 に示すように 5 段階の濃度を用いた10回の測定 結果では沪液と汇過残液に打ける VPA 測定值の相関係 数は 0.995 と高く, VPA のメンブランへの吸着はほと んどないことがわかった。

3）メンブランの均一性

Table 2 そ示すように同一ロットのメンブラン10枚を 用いて行った測定結果では, 遊離型 VPA 濃度の平均值
が $11.35 \mu \mathrm{g} / \mathrm{ml}$ で, 変動係数は $5.5 \%$ でありメンブラ ンの均一性が認められた.

2. EMIT 法と GLC 法における血洋中 VPA 港瀑 度の比校

71検体の血清中 VPA 総浱度を両法で測定した結果を Fig. 6 に示したが，高い相関関保が得られた。

3. EMIT 法と GLC 法における血济中注攸型 VPA 灌度の比荒

48検体の血清中遊離型 VPA 濃度を両法で測定した結 果を Fig.7 に示したが，同様に高い相関関係が得られ た. EMIT VPA Assay Kit をそのまま用いた測定では その測定可能範囲の下限が $10 \mu \mathrm{g} / \mathrm{ml}$ とされており，低 濃度域では日内変動の C.V. 值が大きく, 5) 高めの値が 得られる()こと，また平衡透析して得られた遊離型浱度 を測定すると，GLC 法よりはるかに高い值が得られる67 ことなどが報告されている．しかし著者らが行った低濃 度測定法では, $10 \mu \mathrm{g} / \mathrm{ml}$ 以下の濃度についても GLC 法 による値とよく一致した。

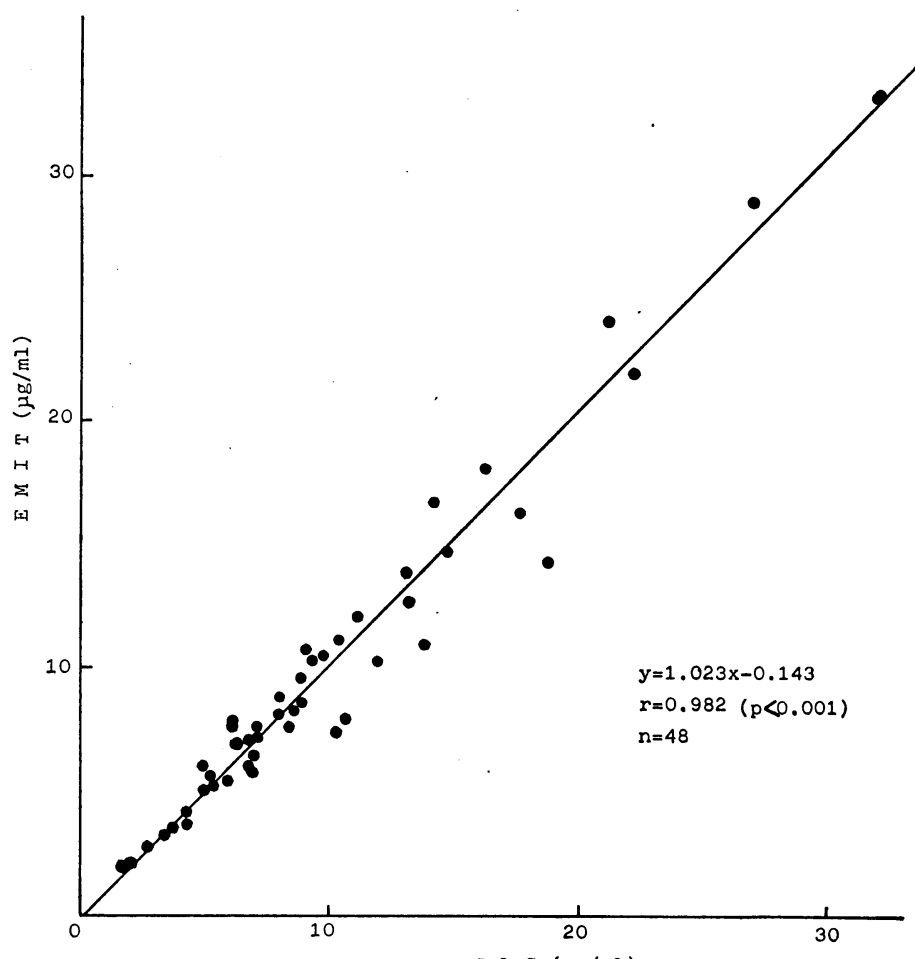

G L C $(\mu \mathrm{g} / \mathrm{m} 1)$

Fig. 7. Comparison of Free VPA Levels Determined by EMIT and GLC 


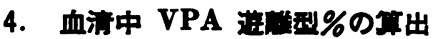

EMIT 法による測定值から算出した結果を Table 3， Table 4 に示した. VPA 単独服用時での遊離型\%の平 均值および標準偏差は $12.5 \pm 3.9 \%(n=20)$ であっ た. 他の抗てんかん薬併用時では $5.0 \%$ から $23.9 \%$ の 範囲であり，PB，PB+PHT 併用時の遊離型\%はいずれ むVPA 単独服用時の值と比較して, 検定 $(\mathrm{t}-$ 検定 $) の$ 結果, 有意差は認められなかったが, $\mathrm{CZP}, \mathrm{CBZ}, \mathrm{PB}+$ CZP 併用時では有意差が認められた $(\alpha=0.01) . \mathrm{PB}+$ PHT+CZP 併用時では検体数が少ないため比較できな かった.

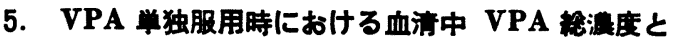 进型型\%との間保}

Fig.8 亿示すように, VPA 遊離型\%は VPA の総濃 度が大きくなるに従い增加し, 相関係数が 0.808 で正 の相関関俰が認められた．血墏蛋白との結合定数の高い 薬物では遊離型薬物の割合に濃度依存性がある7゙といわ れているが，VPA の場合にも同様の傾向が認められ た.

\section{結的畣}

血清中遊離型 VPA の分離に用いた遠心型蛋白結合試 験器 MPS-1 は少量の試料でかつ短時間で分離でき, 方 法も簡便であることから臨床上実用性があると認めた. また EMIT を利用した低濃度測定法は, GLC 法との相 関係数が 0.982 と高く有用であった.

血清中 VPA の遊離型\%は, VPA 単独服用時では $12.5 \pm 3.9 \%$ Wulff, ${ }^{8)}$ Löscher, $\left.{ }^{9}\right)$ Bruni ${ }^{10)} ら の$ 報告に 近い值が得られ, VPA の遊離型\%は総濃度に依存して いることが認められた．また他の抗てんかん薬との併用 では，少数例ではあるが VPA の遊離型\%に対する影響 は, 検定 ( $\mathrm{t}$-検定) の結果明らかには認められなかっ た. 今後は抗てんかん薬の相互作用を遊離型濃度のレべ ルでる検討する必要があると思われた。

愔辞 本実験にあたり検体を提供していただいた旭川 医科大学附属病院小児科, 長 和彦講師, 沖潤一助手, また，血清中総蛋白を测定していただいた検査部，森山 隆則技師に感謝します.

Table 3. Analytical Results (1)

\begin{tabular}{|c|c|c|c|c|}
\hline Sample & $\begin{array}{l}\text { Total VPA } \\
\text { (EMIT) }\end{array}$ & $\begin{array}{c}\text { Free VPA } \\
(\text { EMIT) }\end{array}$ & $\%$ Free VPA & Mean $\pm S D$ \\
\hline$V P A$ & $\begin{array}{l}172.0 \mu \mathrm{g} / \mathrm{ml} \\
171.0 \\
170.0 \\
168.0 \\
145.0 \\
126.5 \\
117.0 \\
102.5 \\
102.0 \\
96.0 \\
89.0 \\
87.0 \\
87.0 \\
79.0 \\
67.5 \\
65.5 \\
52.5 \\
35.0 \\
30.0 \\
15.0\end{array}$ & $\begin{array}{r}33.2 \mu \mathrm{g} / \mathrm{ml} \\
33.4 \\
22.0 \\
29.0 \\
24.2 \\
18.4 \\
16.4 \\
14.0 \\
9.6 \\
11.2 \\
10.8 \\
7.6 \\
14.4 \\
7.5 \\
8.9 \\
6.0 \\
3.6 \\
3.3 \\
2.1 \\
1.4\end{array}$ & $\begin{array}{r}19.3 \% \\
19.5 \\
12.9 \\
17.3 \\
16.7 \\
14.5 \\
14.0 \\
13.7 \\
9.4 \\
11.7 \\
12.1 \\
8.7 \\
16.6 \\
9.5 \\
13.2 \\
9.2 \\
6.9 \\
9.4 \\
7.0 \\
9.3\end{array}$ & $\begin{array}{c}12.5 \pm 3.9 \% \\
(n=20)\end{array}$ \\
\hline
\end{tabular}


Table 4. Analytical Results (2)

\begin{tabular}{|c|c|c|c|c|}
\hline Sample & $\begin{array}{l}\text { Total VPA } \\
\text { (EMIT) }\end{array}$ & $\begin{array}{c}\text { Free VPA } \\
(\text { EMIT) }\end{array}$ & $\%$ Free VPA & Mean $\pm S D$ \\
\hline 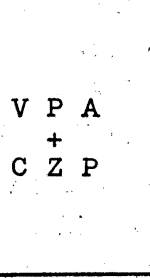 & $\begin{array}{r}152.0 \mu \mathrm{g} / \mathrm{ml} \\
142.0 \\
99.0 \\
94.0 \\
87.5 \\
86.0 \\
81.0 \\
74.0 \\
56.0 \\
\end{array}$ & $\begin{array}{r}31.8 \mu \mathrm{g} / \mathrm{ml} \\
34.0 \\
16.8 \\
6.6 \\
12.8 \\
12.2 \\
11.0 \\
8.6 \\
8.2 \\
\end{array}$ & $\begin{array}{r}20.9 \% \\
23.9 \\
17.0 \\
7.0 \\
14.6 \\
14.2 \\
13.6 \\
11.6 \\
14.6 \\
\end{array}$ & $\begin{array}{c}15.3 \pm 4.9 \% \\
(n=9)\end{array}$ \\
\hline $\begin{array}{l}\mathrm{V} \quad \mathrm{P} A \\
\stackrel{+}{\mathrm{C}} \mathrm{B} Z\end{array}$ & $\begin{array}{l}76.0 \\
66.0 \\
63.0 \\
43.5 \\
29.0 \\
\end{array}$ & $\begin{array}{l}6.4 \\
5.8 \\
5.2 \\
3.7 \\
2.8 \\
\end{array}$ & $\begin{array}{l}8.4 \\
8.8 \\
8.3 \\
8.5 \\
9.7 \\
\end{array}$ & $\begin{array}{c}8.7 \pm 0.6 \% \\
(n=5)\end{array}$ \\
\hline $\begin{array}{l}\mathrm{P} A \\
\mathrm{P}^{+} \mathrm{B}\end{array}$ & $\begin{array}{l}96.0 \\
91.0 \\
79.0 \\
73.5 \\
63.0 \\
61.9 \\
59.0 \\
53.0 \\
47.5 \\
42.5 \\
30.5 \\
\end{array}$ & $\begin{array}{r}10.4 \\
14.2 \\
13.4 \\
12.9 \\
7.2 \\
3.9 \\
11.0 \\
9.8 \\
8.0 \\
4.2 \\
4.0 \\
\end{array}$ & $\begin{array}{r}10.8 \\
15.6 \\
17.0 \\
17.6 \\
11.4 \\
6.4 \\
18.6 \\
18.5 \\
16.8 \\
9.9 \\
13.1 \\
\end{array}$ & $\begin{array}{c}14.2 \pm 4.1 \% \\
(n=11)\end{array}$ \\
\hline $\begin{array}{l}V P A \\
+{ }^{+} B \\
P \stackrel{H}{+} T\end{array}$ & $\begin{array}{r}110.0 \\
88.0 \\
85.0 \\
80.5 \\
78.0 \\
76.5 \\
63.5 \\
63.0 \\
61.0 \\
55.0 \\
25.0\end{array}$ & $\begin{array}{r}18.2 \\
7.0 \\
7.7 \\
5.4 \\
7.9 \\
8.3 \\
10.4 \\
5.1 \\
7.6 \\
10.8 \\
2.0\end{array}$ & $\begin{array}{r}16.5 \\
8.0 \\
9.1 \\
6.7 \\
10.1 \\
10.8 \\
16.4 \\
8.1 \\
12.5 \\
19.6 \\
8.0 \\
\end{array}$ & $\begin{array}{c}11.4 \pm 4.3 \% \\
(n=11)\end{array}$ \\
\hline $\begin{array}{c}\mathrm{V} P \mathrm{~A} \\
+{ }^{+} \mathrm{B} \\
+\mathrm{C}^{+} \mathrm{P}\end{array}$ & $\begin{array}{r}126.0 \\
118.0 \\
115.0 \\
105.0 \\
100.0 \\
94.5 \\
89.5 \\
84.5 \\
77.5 \\
67.0 \\
55.0 \\
50.0 \\
\end{array}$ & $\begin{array}{r}6.6 \\
6.1 \\
7.0 \\
6.0 \\
9.2 \\
7.1 \\
10.6 \\
7.4 \\
3.9 \\
4.7 \\
5.7 \\
5.3 \\
\end{array}$ & $\begin{array}{r}5.2 \\
5.2 \\
6.1 \\
5.7 \\
9.2 \\
7.5 \\
11.8 \\
8.8 \\
5.0 \\
7.0 \\
10.4 \\
10.6 \\
\end{array}$ & $\begin{array}{c}7.7 \pm 2.4 \% \\
(n=12)\end{array}$ \\
\hline $\begin{array}{r}\mathrm{VPA}+\mathrm{PB} \\
+\mathrm{PHT} \\
+\mathrm{CZP}\end{array}$ & 115.0 & 14.8 & 12.9 & \\
\hline
\end{tabular}




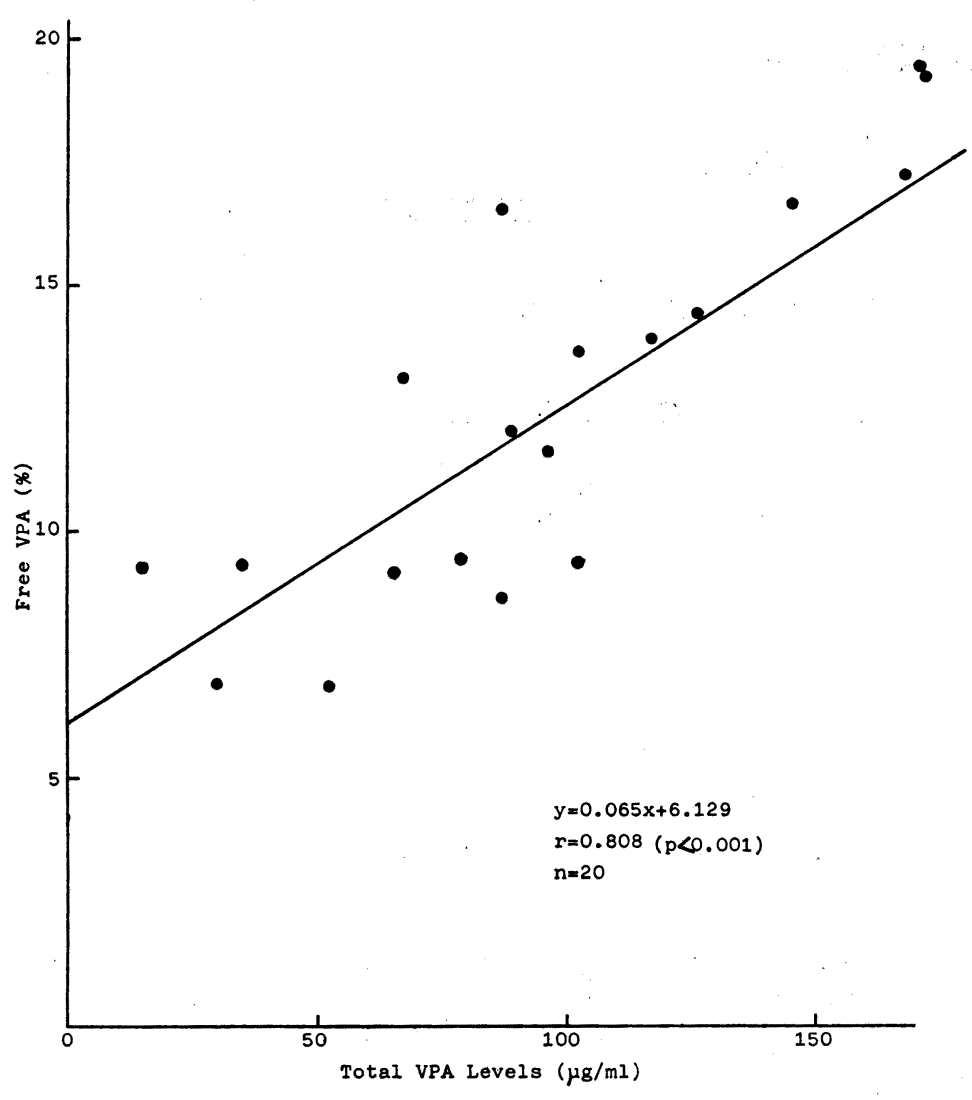

Fig. 8. Relationship between $\%$ Free VPA and Total VPA Levels (EMIT)

文

能

1) H.Kurz, H.Trunk, and B. Weitz : Arzneim.Forsch., 27 (II), 1373 (1977).

2）金井泉，金井正光編 : “臨床検査法提要,”金原出 版, 東京, 1978.

3）赫川夫, 宫越雅子, 坂昌史, 清野昌一, 和田 豊治 : 卧床精神医学, 7, 321 (1978).

4）幸田幸直, 西原カズョ, 斎藤也, 中川冨士雄, 田村善蔵：医学のあゆみ, 115, 813 (1980).

5) C.De Porceri-Morton, J. Turner, and R. Bastiani : "EMIT Valproic Acid Assay Clinical
Study No. 80 Summary Report," Syva Co., Palo Alto, U.S.A.,1980.

6) N. Buchanan, P. Ponniah : Med. J. Austl.,1, 539 (1981).

7) M.C.Meyer, D.E.Guttman : J. Pharm. Sci., 57, 895 (1968).

8) K. Wulff, H. Flachs, A. Würtz-J $\phi$ rgensen, and L. Gram : Epilepsia, 18, 149 (1977).

9) W.Löscher : J. Pharmacol. Exp. Ther., 204, 255 (1978).

10) J.Bruni, J.M.Gallo, and B. J. Wilder : Can. J. Neurol. Sci., 6, 453 (1979). 